\title{
Land Grant Cancellation and its Legal Consequences to the Right Transfer Certificate
}

\author{
A B Rangkuti ${ }^{1}$ and $S$ Kalo ${ }^{2}$ \\ Law Program, Universitas Sumatra Utara, Medan, Indonesia \\ ${ }^{1}$ budir1312@gmail.com
}

\begin{abstract}
The grants violating legitiemeportie is sometimes canceled by a judicial institution such as in the Medan District Court verdict No. 506/Pdt.G/2008/PNMdn. One of its decisions states that the grant deed becomes null and void by the law. Therefore, it is necessary to study the rights of heirs to their parents' assets that have been granted and have been renamed on behalf of the recipient of the grant, and to determine the legal consequences due to the cancellation of the land right transfer certificate. This research is a legal research. The method used is a normative legal research with a descriptive analysis. The findings show that the heirs are allowed to file claims to calculate or return all the properties previously received from the dead during his lifetime into the origin wealth (boedel) calculation to be shared with other heirs. In this case, the family relationship between the heirs and their stepmother (the wife of the owner) is in a conflict. The object being sued is a house which is neglected thus disturbing the surrounding housing complex.
\end{abstract}

Keywords: Judicial, Legal research, legitiemeportie

\section{INTRODUCTION}

Each land title transfer must be registered to the local Land Office where the land is located after getting a prior deed of Land Deed Official (PPAT). Such registration is necessary for the land title transfer to have a strong legal force; consequently, if someday there is a land dispute and the grantee has an authentic evidence of the land title certificate, then he/she will be protected by the law. One form of land disputes concerning a title transfer arises because of a lawsuit for acancellation of land title transfer.

A grant is essentially irrevocable, but it can be withdrawn or abolished if meeting the provisions of Article 1688 of the Civil Code as follows:

- The conditions under which the grant is made are not met;

- The grantee is guilty for committing or assisting a crime of murdering the grantor or any other crime against the grantor;

- The grantee refuses to provide subsistence allowance to the grantor, after the quality of the grantor's life deteriorates.

Based on the above descriptions, it is necessary to conducta further study on legal consequences of land title transfer cancellationover the land certificate. In accordance with 
such necessity, this study focuses on analyzing a land grant cancellation and its legal consequences to the right transfer certificate.

\section{METHODS}

Based on the background elaborated above, the problems of this study are formulated in the following questions: How is the use of canceled grant land to the environment?

This is descriptive analytic research. Descriptive research is expected to reveal a detailed and systematic description of the problem. In addition, analytic means a careful analysis in answering the problem is based on the facts.

This research is expected to provide explanations (i) whether the court's decision is appropriate and in accordance with the system of land registration in Indonesia; (ii) whether the procedure of canceling a certificate by the National Land Agency corresponds to the prevailing laws and regulations; and (iii) how a legal certainty is given to the grant-based certificate that can, therefore, explain the legal consequences of the cancellation over the grant-based certificate to the legitimaris (legitimate offsprings).

\section{RESULT and DISCUSSION}

According to the provisions of Article 875 of the Civil Code, a testament is a legal document through which a deceased person disposes his property, which he/she can revoke. The designated person who will receive the property if he dies is called a legatee. Alegatee is an heir under a special title. Sincea testament is a unilateral statement, each notary deed ona testament can be revokedat a time or at any time by a testator [1].

According to the Civil Code, a testament has two characteristics, namely: firstly,it applies only after the testator dies; and secondly, it can be revoked as long as the testator is still alive [2].

Inexistenceof one of the two characteristicsmakesa testament not existed. This means that the legal document is no longer a testament [3]. So, the characteristic of "revocable" is a very determinative factor in a testament. Alegal interpretationof the Civil Code views a testament asa unilateral legal action,although unilateral characteristic does not define the existence of a testament.

Parties in the making a testament, are:

- A testator, is a person who executes or signs a testament, who will dispose his property if he dies;

- A beneficiary of a testament, called a legatee, is adesignated person to receive a property under a testament;

- An executor, called an ExecuteirTestamentair, is a person nominated to administer and manage a testament; [4]

- A notaryis an authorized official in making an authentic deed, including a deed of a testament.

- Witnesses, those who attend the making of a testament.

Furthermore, of course, the most important thing is the property to be disposed. Generally in a testament, atestator appointsa person to be a beneficiary as well as to be an executor of a testament. However, he can appointother person to be an executor, not the beneficiary. In this case, alegatee may ask the heirs or executor to hand the granted property. For this, the heirs or executors and the legatee must make a legaat, a hand over deed. 
According to Article 1666 of the Civil Code, a grant is formulated as follows: "Grant is an agreement whereby agrantor, in his lifetime, freely and irrevocably, gives something for the benefit of a grantee's". Grants can only be in the form of identifiable objects. If a grant includes future existing objects, then the grant is invalid (Article 1667 of the Civil Code).

Several factors that make a grant invalid are; the grant includes future existing objects; the grantorpromises that he still tries to sell or give one or some parts of the objects to other parties; the grant is madeunder a condition that the grantee will pay off the grantor's debts or other expenses; and, the grantee is immature and/or incompetent [5].

The legal consequence of a grant being challenged for a cancellation in a court with a permanent legal force verdict that annuls thegrantis to return the ownership of the property to the grantor. Simply, all assets that have been granted in the past will return to the grantor. For example, if a person grants a plot of land or a house, then with a verdict cancelingthe grant,such land or house will become the property of the grantor again [6].

In the case of a grant cancellation occurring in the Medan District Court Number 506/Pdt.G/2008/PN-MDN on June 10, 2009, in the appeal court of the North Sumatra High Court Decision No. 297/PDT/2009/ PT.MDN on May 22, 2009, and at the cassation level at the Supreme Court of the Republic of Indonesia Decision No. 2711 K/Pdt/2010 on March 25, 2011, one of the decisions states the Grant Deed No. 180/2002 on August 19, 2002 which was administered by Reny Helena Hutagalung, a Land Registrar in Medan City,is invalid and null by the law. Therefore, the ownership of the land with an Ownership Certificate No. 254/SeiSikambing-B returns to the grantor, Herminder Singh, to be recalculated according to the parts inherited by his heirs. Thus, a legal consequence of a permanent legal force decision cancelinga grant makes the land, as the object of dispute,to be returned to the grantor along with all the rights attached.

However, based on the Medan District Court Decision Number 506/Pdt.G/2008/PNMDNon June 10, 2009 in conjunction withthe North Sumatra High Court Decision No 297/PDT/2009/PT.MDN on May 22, 2009 in conjunction with the Supreme Court of the Republic of Indonesia Decision No. 2711 K/Pdt/2010 on March 25, 2011, the judges, in deciding that the land right transfer by the grantor made before Reny Helena Hutagalung, a Land Registrar in Medan City is invalid and null, do not consider whether LegitiemePortieof the ab-intestato (by intestacy) heirs of Herminder Singh has been violated or not. The cancellation of the land right transferwas carried out based on the consideration that the grantor in executing his legal action was incompetent due to a severe illness; and, the granted land was part of ashared property with his first wife. The provisions of the prevailing law, for non-Chinese east foreign family, do not define a shared or a mixture of assets. Hence, the granted land, obtained by the grantor at the time of his marriage with the first wife, is the property of the grantor. Then, the grantor could grant his asset to the child of the second wife, as long as the legitiemeportie of the ab-intestato heirs is not violated.

Based on the court's decision, the legitiemeportie is not violated. The cancelation of the grant has made the property being neglected and the family relationship is worsening due to uncompromisingdecision among them. After a long deliberation, the heirs took the case to court and the court canceled the grant. Finally, the certificate title is returned to the grantor (his heirs).

\section{CONCLUSION}

The heirscan claim their parent's property that has been granted and has been transferred to the title of the grantee, to be recalculated or returned all the property previously received from 
the dead during his life into the origin wealth (boedel) calculation to be shared with other heirs. It is in accordance with the inbreng(recalculation of wealth) function, i.e. to ensure a justice or equality amongstthe children in receiving the share of any transfer of their parent's property. Such property transfer includes either the transfer during their parent's lifetime or after their parent's death in the form of grant or after-death transfer through division of inheritance, especially the one related to a legitimieportie or the part that must be received by the heirs; therefore, each of the children will get their share. A canceled grant on a house makes the house being neglected and not being used properly as intended thus disturbing its surrounding. The cancelation also makes the family relationship is not harmonious.

The findings suggest that in the process of granting, it is necessary to comply with the prevailing norms, i.e. propriety, religious and moral norms. Since they will restrict the possibility of grant cancellation due to a bad behavior of the grantee after obtaining the granted property. Besides, a Notary or Land Deed Official (PPAT) as the official authority to undertake the process of right transfer on whom the parties rely should be more careful and conscientious, especially regarding the rights of other heirs which are likely to be violated due to the grant.

\section{REFERENCES}

[1] H. Soerjopratiknjo, Hukum Waris Testamenter, 1st ed. Yogyakarta: Seksi Notariat Fakultas Hukum Universitas Gadjah Mada, 1982.

[2] A. Afandi, Hukum Waris, Hukum Keluarga dan Hukum Pembuktian. Jakarta: PT Rineka Cipta, 1997.

[3] Oemarsalim, Dasar-Dasar Hukum Waris di Indonesia. Jakarta: Rineka Cipta, 1991.

[4] T. T. Tutik, Hukum Perdata dalam Sistem Hukum Nasional. Jakarta: Prenada Media Grup, 2008.

[5] M. I. Ramulyo, Beberapa Masalah Pelaksanaan Hukum Kewarisan Perdata Barat (Burgerlijk Wetboek). Jakarta: Sinar Grafika, 1993.

[6] M. Rusmadi, Penyelesaian Sengketa Hukum Atas Tanah. Jakarta: Alumni, 1991. 